\title{
Judicial Review of Administrative Action at National Level under the EU Charter of Fundamental Rights and General Principles of EU Law
}

\author{
Mihaela Vrabie \\ University of Bucharest, Faculty of Law, Romania \\ mihaela.vrabie@drept.unibuc.ro \\ https://orcid.org/0000-0002-1509-1393
}

Received: 4. 9. 2019

Accepted: 5. 4. 2020

\section{ABSTRACT}

This article aims to determine when the national authorities have the obligation to comply with EU fundamental rights, in the framework of administrative procedures carried out in the EU Member States. It also aims to determine the legal remedies available at national level in the context of judicial review in case of violation, by the national authorities, of EU fundamental rights guaranteed by the Charter of Fundamental Rights of the EU or as general principles of EU law. To this end, this study explains the impact of the legally binding EU Charter on public administration of the Member States and the field of application of the EU Charter at national level. The article also deals with the distinction between EU fundamental rights as primary EU law guaranteed by the EU Charter and EU fundamental rights as general principles of EU law. With reference to the judicial remedies available to national courts, the study outlines the effects of EU law (primacy of EU law, direct effect, direct application) in relation to the EU fundamental rights and the measures that can be adopted by the national courts when the action of the national administrative authorities is not compatible with EU fundamental rights. Finally, the article presents the most important findings concerning judicial protection of EU fundamental rights at the national level, especially from the perspective of the right to an effective remedy and to a fair trial stipulated by Article 47 of the EU Charter.

Keywords: Charter of Fundamental Rights, general European principles, primacy of EU law, right to a good administration, right to an effective remedy, judicial review

JEL: K10 


\section{Introduction}

One of the main legislative changes introduced by the Treaty of Lisbon ${ }^{1}$ in the area of fundamental rights protection in the European Union is represented by the official recognition of the Charter of Fundamental Rights of the European Union as a legally binding instrument, having the same legal value as the Treaties of the European Union. ${ }^{2}$

The entry into force of the EU Charter on December 2009 reaffirmed the EU's commitment to the protection of fundamental rights and created the necessary legal framework for the accomplishment of a better legal enforcement of fundamental rights at the European Union level.

As a consequence, since December 2009, the EU Charter is a part of EU primary law, it is supreme over national law of Member States, it is a directly applicable rule of law at national level and it has direct effect, in the same conditions established by EU law for the Treaties of the European Union.

According to Article 51 (1) of the EU Charter, ${ }^{3}$ EU institutions, bodies, offices and agencies must comply with the EU Charter in all their actions, while Member States must comply with EU Charter only when they are implementing EU law. This means that the EU Charter is the principal measuring instrument for legality for the actions of EU institutions, as well as for the actions of Member States when they implement EU law.

Although since December 2009, the EU Charter is a legal instrument of outstanding importance for the protection of fundamental rights, at EU and national level, the official reports of the $\mathrm{EU}$ institutions still recall the importance of awareness-raising on the application of the EU Charter at national as well as at EU level among policymakers, legal practitioners and the rights holders themselves (Council of the EU, 2017, p. 3; European Commission, 2018, p. 13; European Union Agency for Fundamental Rights, 2018, p. 3). In this context, it is worth mentioning that the results of a recent Eurobarometer survey highlight that only $42 \%$ of respondents have heard of the EU Charter and only $12 \%$ really know what it is (European Commission, 2019, p. 3). This is because the EU Charter still raises a number of concerns and uncertainties related to its interpretation and field of application, especially at national level. The fact that the general principles of EU law are still protected by EU law as a distinct source of EU fundamental rights, after the entry into force of the EU Charter) increases the uncertainties related to the application of EU fundamental rights at national level.

Since at national level, the main institutional actors which must ensure compliance with EU Charter and with the general principles of EU law are the na-

1 Treaty of Lisbon amending the Treaty on European Union and the Treaty establishing the European Community, OJ C 306, 17. 12. 2007 (entry into force on 1 December 2009).

2 According to Article 6 (1) TEU, as it was modified by the Treaty of Lisbon: "The Union recognizes the rights, freedoms and principles set out in the Charter of Fundamental Rights of the European Union of 7 December 2000, as adapted at Strasbourg, on 12 December 2007, which shall have the same legal value as the Treaties."

3 OJ C 326, 26. 10.2012. 
tional legislative and administrative authorities and the public institutions (as representatives of the Member States), when they are implementing EU law, this article aims to contribute to awareness-raising on the application of the EU Charter and of the general principles of EU law at national level in the national administrative procedures and also to outline what legal remedies are available at national level when the EU fundamental rights are not observed by the national administrative authorities.

In order to achieve this scope of work, this paper will examine the scope of application of EU Charter and of the general principles of EU law at national level, by outlining the specific situations in which the national administrative authorities have the legal obligation to comply with the provisions of the EU Charter (or with the general principles of EU law), based on the most relevant CJEU case-law related to Article 51 of the EU Charter and to the application of general principles of EU law.

Since the EU Charter and the general principles of EU law are two different sources of EU fundamental rights that are both applicable at national level, the paper also emphasizes the distinction between EU fundamental rights as primary EU law guaranteed by the EU Charter and EU fundamental rights as general principles of EU law, with the purpose of highlighting the most effective procedural means of claiming, in national courts, violation of EU fundamental rights. The analysis of the distinction is based on the most recent CJEU decisions in connection with the EU fundamental rights most often invoked in the administrative proceedings as being violated by the public administration of the Member States - the right of defence, the presumption of innocence and the right to a good administration - especially in the matters related to national competition authorities and tax authorities.

For the purpose of an in-depth practical understanding of the subject, the paper will deal, in Section 4, with the practical relevance of the distinction between the EU Charter and the general principles of EU law and will explain when certain EU fundamental rights are applicable at national level as general principles of EU law and when are applicable as rights enshrined by the EU Charter.

In the context of judicial review, the paper analyzes also the legal remedies available in the context of national judicial review of the national administrative decisions, in case of violation of EU fundamental rights guaranteed by EU Charter (or of the general principles of EU law), trying to determine when the EU fundamental rights can be invoked before the national courts based on the direct effect of EU law and when the national courts can decide the annulment of the decisions of the national public administration which are not compatible with EU fundamental rights. Moreover, the article will examine, as a case study, the most relevant judgements delivered in Romania which deal with the judicial review of national measures for compliance with EU Charter and with general principles of EU law. 


\section{Methods}

This study is based, mainly, on relevant CJEU case-law, legislation and papers regarding the field of application of EU Charter to Member States. Also, this study analyzes post-Lisbon CJEU case-law concerning the application of certain EU fundamental rights at national level, in the context of national administrative proceedings (the right of defence, the presumption of innocence and the right to a good administration) in order to highlight the distinction between the general principles of EU law and the rights enshrined by the EU Charter. For this analysis, were selected the most often invoked EU fundamental rights in the administrative proceedings as being violated by the public administration of the Member States, especially in the matters related to national competition authorities and tax authorities. In order to illustrate practical and concrete examples of national judicial review of the national administrative action for compliance with EU Charter and general principles of EU law, the article examines and presents the most relevant judgements delivered in Romania by the Romanian Constitutional Court and the High Court of Cassation and Justice. Official reports of the relevant EU institutions are also analyzed.

\section{The field of application of EU Charter at national level. When must national authorities comply with the legally binding EU Charter?}

According to Article 51 (1) of the EU Charter, Article 6 (1) and Article 6 (3) TEU, ${ }^{4}$ Member States - including all national institutions, authorities, bodies, offices and agencies - must comply with the EU Charter "only when they are implementing EU law".

Whilst Article 51(1) of the EU Charter, which defines the field of application of the EU Charter, clearly states that Member States are bound by the EU Charter "only when they are implementing EU law", the field of application of EU Charter regarding acts adopted by Member States and national authorities raised a number of uncertainties. Besides, the scope of application of EU law has been extended, as the CJEU case-law shows, ${ }^{5}$ to include acts adopted by the national authorities that constitute derogations from provisions of EU law, or acts adopted by the national authorities that only remotely are connected with EU law.

The definition of the field of application of the EU Charter with regard to Member States and national authorities is directly related to the interpretation of the notion of "implementing EU law" used by article 51(1) of the EU Charter, the essential question being whether the expression refers only to the transposition of EU law into national legislation, or it may be extended beyond these limits, with the direct consequence of extending the limits of

4 TEU version after the entry into force of the Treaty of Lisbon.

5 Case C-60/00, Carpenter, CJEU; Case C-71/02, Karner, CJEU; Case C-36/02, Omega, CJEU; Case C208/09, Wittgenstein, CJEU; Case C33/07, Jipa, CJEU. 
the application of the EU Charter to any measure or act of the Member States and of the national authorities which falls within the scope of EU law.

Since Article 51(1) of EU Charter does not give a complex definition of the notion of "implementing EU law", different opinions have been issued, after the entry into force of the EU Charter. The majority of scholars (Schwarze, 2001, pp. 407-410; Garcia, 2002, pp. 492-514; Eeckhout, 2002, pp. 945-994) supported an extensive interpretation of Article 51(1) of the EU Charter, according to which the implementation of EU law refers to all situations when Member States and national authorities are acting within the scope of EU law, even when Member States and national authorities are derogating from EU law or attempting to obtain an exemption from the application of EU law.

The Explanations relating to the EU Charter ${ }^{6}$ ("Explanations") and the relevant decisions of the CJEU rendered after the entry into force of the EU Charter, in cases concerning the compatibility of acts adopted by the national authorities with the EU Charter, clarified the uncertainties related to the interpretation of Article 51 (1) of the EU Charter and of the notion "implementing EU law", by embracing, officially, the extensive interpretation of Article 51(1) of the EU Charter.

First of all, the Explanations bring a broader perspective over the field of application of the EU Charter with regard to Member States, mentioning the pre-Lisbon case-law of the Court of Justice of the European Union, ${ }^{7}$ which means that the non-compliance of the national authorities with the EU Charter "will be assessed whenever the national action (or omission) comes within the gravitational orbit of Union law" (Di Federico, 2011, p. 40). The message transmitted by the Explanations is that "Member States are bound by fundamental rights when they act in the scope of Union law, and that the phrase <implementing Union law > is intended to capture the various senses in which Member States could be said to be acting in the scope of Union law" (Craig, 2010, p. 212).

But above all, the most significant indicator in determining the situations in which national authorities must comply with the provisions of the EU Charter remains the CJEU case-law rendered after the EU Charter became legally binding, because all the national courts and all the national authorities must observe the CJEU's judgments with regard to the interpretation of EU law when they are confronted with a problem of the same nature. ${ }^{8}$

In this context, the most relevant and important decision of the CJEU rendered after the entry into force of the EU Charter, with reference to the interpretation of Article 51(1) of the EU Charter, is the decision rendered in case Fransson, ${ }^{9}$ where CJEU clearly embraced the extensive interpretation of the

6 Explanations related to the Charter of Fundamental Rights of the European Union, OJ C 303, 14.12.2007, p. 18.

7 Case C-60/00, Carpenter, CJEU; Case C-71/02, Karner, CJEU.

8 Case C-106/77, Simmenthal, CJEU and case C-61/79, Denkavit, CJEU. This obligation arises also from the principle of sincere cooperation, established by Article 4 (3) TEU.

9 Case C-617/10, Fransson, CJEU. 
notion "implementing EU law" which defines the field of application of the EU Charter to Member States.

In Fransson case, CJEU defined the notion "implementing EU law" by ruling that "the fundamental rights guaranteed by the Charter must therefore be complied with where national legislation falls within the scope of European Union law" ${ }^{10}$ and that "the applicability of European Union law entails applicability of the fundamental rights guaranteed by the Charter". ${ }^{11}$ Within the same context, the CJEU held that in Fransson case, the Member State was implementing EU law within the meaning of Article 51 (1) of the EU Charter (even if the national legislation in question was not adopted to transpose an EU Directive), because "its application is designed to sanction an infringement of that directive and is therefore intended to implement the obligation imposed on the Member States by the Treaty to impose effective penalties for conduct prejudicial to the financial interests of the European Union." ${ }^{12}$

It follows clearly that by this ruling, CJEU adopted a wide and extensive interpretation of the notion "implementing EU law" in the meaning of Article 51(1) of the EU Charter and subsequently, a wide understanding of the field of application of the EU Charter to Member States and to national authorities. Thus, this ruling extends also the number of situations and cases at national level in which the national authorities must comply with the rights laid down by the EU Charter.

It can be concluded, from the Fransson case, but also from other CJEU caselaw delivered after the entry into force of the EU Charter, ${ }^{13}$ what are the specific situations when Member States actions - including the measures, the acts or the decisions of the national authorities (administrative authorities, public institutions, etc.) - fall within the scope of EU law and consequently, must comply with the fundamental rights laid down by the EU Charter:

- when Member States/national authorities are implementing EU law, ${ }^{14}$ acting as agents of the European Union, adopting administrative or legislative acts in order to implement EU regulations, transpose EU directives or apply EU decisions;

- when Member States/national authorities are derogating from EU law; ${ }^{15}$

- when Member States/national authorities are acting within the scope of EU law, adopting national law or adopting national acts/measures/decisions that fall within the scope of application of EU law, either because the

10 Case C-617/10, Fransson, CJEU, para. 21.

11 Case C-617/10, Fransson, CJEU, para. 21.

12 Case C-617/10, Fransson, CJEU, para. 28.

13 Case C-34/09, Zambrano, CJEU; Case C-249/11, Byankov, CJEU; Joined Cases C-411/10 and C-493/10, N.S. and Others, CJEU; Case C-27/11, Vinkov, CJEU; Case C-279/09, DEB, CJEU.

14 Case C-5/88, Wachauff, CJEU; Case C-442/00, Cabalero, CJEU; Joined Cases C-465/00, C-138/01 and C-139/01, Rechnungshof, Neukomm and Lauermann, CJEU; Case C-78/11, Anged, CJEU; Case C-555/07, Kücükdeveci, CJEU; Case C-101/01 Lindqvist, CJEU.

15 Case C-260/89, Elliniki Radiophonia Tileorassi (ERT), CJEU; Case C-60/00, Carpenter, CJEU; Case C-71/02, Karner, CJEU; Case C-208/09, Sayn-Wittgenstein, CJEU; Case C-36/02, Omega, CJEU. 
national legislation or national action is connected in any way with EU law, or because the subject matter of the national legislation or of the national action in question is governed by a legally binding provision of EU law ${ }^{16}$ (other than the EU Charter).

With reference to the categories of national legislative and administrative authorities that are responsible with ensuring compliance with the provisions of EU Charter and application of the rights stipulated by the EU Charter in national legislative or administrative procedures, the Explanations mention that the EU Charter applies to the central authorities as well as to regional or local bodies, and to public organizations. ${ }^{17}$

In conclusion, the field of application of the EU Charter with regard to Member States is not narrow, but a large and complex one, since all the central authorities as well as regional or local bodies (including administrative authorities), and also public organizations must comply with the provisions of EU Charter whenever they implement EU law, derogate from EU law or when they adopt measures that fall within the scope of EU law.

Even if the Explanations do not mention the national courts among the national authorities which must apply the EU Charter, it is understood, from the fact that the national courts are among the most important national authorities as part of judicial system, that they also have the obligation to comply with the provisions of EU Charter when are confronted with cases that fall within the scope of EU law.

Providing a more exhaustive description of the national actors which have the obligation to implement the EU Charter at national level, the European Union institutions mentioned that "national authorities (judicial authorities, law enforcement bodies and administration) are key actors in giving concrete effect to the rights and freedoms enshrined in the Charter" (European Union Agency for Fundamental Rights, 2018, p. 12). Also, it has been outlined that the duty to respect the EU Charter when implementing EU law "rests on all organs of the Member States, including national lawmakers, administrations, judges, etc." (European Union Agency for Fundamental Rights, 2018, p. 25).

\section{Distinction between EU fundamental rights as general principles of EU law and EU fundamental rrights laid down by the Charter of Fundamental Rights of the European Union}

Before the EU Charter became a legally binding instrument, national authorities had to comply with EU fundamental rights as general principles of EU law, derived from various international instruments and constitutional traditions

16 Case C-617/10, Fransson, CJEU; Case C-34/09, Zambrano, CJEU; Case C-249/11, Byankov, CJEU; Joined Cases C-411/10 and C-493/10, N.S. and Others, CJEU; Case C-27/11, Vinkov, CJEU; Case C-279/09, DEB, CJEU.

17 Explanations related to the Charter of Fundamental Rights of the European Union, OJ C 303, 14.12.2007 - Explanation on Article 52 - Scope and interpretation of rights and principles. 
common to Member States. ${ }^{18}$ Also, long prior to the entry into force of the EU Charter, the CJEU exercised jurisdiction to review acts of Member States within the scope of EU law for compliance with the general principles of EU law (Craig and de Burca, 2011, p. 395; Bazzocchi, 2011, p. 60). ${ }^{19}$

After the entry into force of the Treaty of Lisbon and after the EU Charter became legally binding, EU fundamental rights kept their status as general principles of EU law, ${ }^{20}$ but acquired also a superior legal value - primary law stipulated by the EU Charter, equal to EU Treaties. ${ }^{21}$

It follows that, after the entry into force of the Treaty of Lisbon, according to Article 51 (1) of the EU Charter and Article 6 (1) and (3) TEU, Member States including all national legislative and administrative authorities - must comply with fundamental rights as provisions of the EU Charter but also as general principles of EU law, equally, when they are adopting measures that fall within the scope of EU law.

Regarding the field of application of the general principles of EU law as unwritten court-made general principles that can be invoked before national courts as grounds for legal review of the national action, the pre-Lisbon CJEU case-law established a large perspective over the field of application of the fundamental rights as general principles of EU law to national measures, stating that Member States are bound to respect fundamental rights as general principles when national legislation and measures fall within the scope of EU law, ${ }^{22}$ which is similar to the field of application established by the CJEU for the EU Charter, after its entry into force. That means that all the observations regarding the field of application of the EU Charter which were concluded above in Section 3 of this paper are equally applicable to EU fundamental rights as general principles of EU law.

Regarding the possible derogating effect of the EU Charter from general principles of EU law already existent at the point in time when the EU Charter gained legal force, this is not allowed under the current provisions of Article 6 (3) TEU, which maintain the category of the general principles of EU law as a distinct source of EU fundamental rights, even after the entry into force of the EU Charter (since the same Article 6 TEU recognizes also the legally binding status of the EU Charter and the legally binding status of the general principles of EU law). Article 6 (3) TEU is regarded today as a provision which codifies the case-law of the CJEU on the general principles of EU law (Сraig and de Burca, 2011, p. 366). The general principles of EU law occupy an important place in the normative system of EU law, even after the entry into force of EU Charter, since they are situated on the second tier of the hierarchy on norms,

18 According to Article 6 (2) TEU (version before the entry into force of the Treaty of Lisbon).

19 Case 29/69, Stauder, CJEU, Case 11/70, Internationale Handelsgesellschaft, CJEU, Case 4/73, Nold, CJEU.

20 According to Article 6 (3) TEU (version after the entry into force of the Treaty of Lisbon).

21 According to Article 6 (1) TEU (version after the entry into force of the Treaty of Lisbon).

22 Case C-309/96, Annibaldi, CJEU; Case C-299/95, Kremzow, CJEU; Case C-60/00, Carpenter, CJEU; Case C-71/02, Karner, CJEU. 
after the EU Treaties and the EU Charter (which are situated on the first tier), according to some scholars (Craig and de Burca, 2011, p. 109).

The autonomy of general principles of EU law, after the entry into force of the EU Charter is supported also by Article 6 (1) TEU which makes direct reference to the Explanations of the EU Charter and indirect reference to the sources of the EU Charter, read in conjunction with Article 52 (3) and Article 52 (4) from the EU Charter, which contain guiding lines regarding the interpretation of some provisions of EU Charter and clarify as well the relationship between some provisions of the EU Charter and the general principles of EU law. Thus, according to these provisions, the rights provided by the EU Charter must be interpreted by taking into consideration the equivalent rights provided by the ECHR and by the national Constitutions of the Member States (as general principles of EU law), when the ECHR and the Constitutions of the Member States are the normative sources of the provisions of the EU Charter (Vrabie, 2017, p. 36). It follows that the general principles of EU law continue to exist in EU law as an autonomous source of EU fundamental rights even after the entry into force of EU Charter, since the EU Charter must be interpreted, in certain cases, by taking into consideration the general principles of EU law. This also means that the general principles of EU law were not invalidated by the entry into force of EU Charter - the general principles of EU law continue to apply, in parallel with the provisions of the EU Charter, whose entry into force did not produce a derogating effect on the general principles of EU law.

The autonomy of the general principles of EU law, as a distinct source of EU fundamental rights, even after the entry into force of the EU Charter, was confirmed as well by the case-law of the CJEU which was rendered after the EU Charter became legally binding. Thus, the CJEU continued to recognize the existence and the status of the general principles of EU law after $2009,{ }^{23}$ as it did before the entry into force of the EU Charter. The CJEU continued to take into consideration and to apply both the general principles of EU law and the rights enshrined by the EU Charter, as two different sources of EU fundamental rights, outlining the specificities and the differences between the two sources (e.g. Case C-419/14, WebMindLicences, CJEU, para. 84. or Case C298/16, Ispas, CJEU, para. 26 and 27).

In conclusion, there are two main sources of fundamental rights in EU law, that must be equally observed by the EU institutions and by the national legislative and administrative authorities (and also by national courts): (i) the (unwritten) general principles of EU law identified by CJEU, derived from various international instruments and from constitutional traditions common to Member States and (ii) the EU Charter. These two main sources of fundamental rights provided by EU law must be added to the national legal sources providing fundamental rights. There are many similarities between the two categories provided by EU law (general principles of EU law and EU Charter), because both the general principles of EU law and the EU Charter provisions constitute EU primary law, and they also overlap in many situations with regard to

23 Case C-419/14, WebMindLicences, CJEU. 
the content of the guaranteed right. Also, both categories apply only within the scope of EU law and thus have the same field of application (European Union Agency for Fundamental Rights, 2018, p. 15).

Another important similarity between general principles of EU law and EU Charter derives from the specific effects of EU law in national legal systems - primacy of EU law over national contrary law, direct effect and direct applicability. All these three specific effects of EU law are characteristic for both the general principles of EU law and for the rights enshrined by the EU Charter.

From this perspective, it must be pointed out that the general principles of EU law can have direct effect (under certain conditions even horizontal direct effect) ${ }^{24}$ and can serve as a legal ground for setting aside the national legislation contrary to EU law and as a legal ground for the application of the principle of consistent interpretation (Lenaerts, 2010, p. 224). Also the rights enshrined by the EU Charter can have direct effect and even horizontal direct effects, when certain conditions are met, given the fact that the EU Charter has the same legal value as the EU Treaties. ${ }^{25}$ The CJEU established that a provision of the EU Charter can have horizontal direct effect when the provision of the EU Charter is sufficient in itself to confer on individuals a right which they may rely on as such in a dispute with another individual. ${ }^{26}$

However, the distinction between the general principles of EU law and the rights enshrined by EU Charter is not without relevance.

First of all, the general principles of EU law, together with the case-law of the CJEU, were the legal instruments which allowed the fundamental rights of the Member States and the rights guaranteed by the European Convention of Human Rights to enter the European Union legal order (Tridimas, 2005, p. 298). Since the general principles of EU law are still recognized, after the Treaty of Lisbon, by Article 6 (3) TEU as a legal source with binding legal force, it follows that they still have the potential of continuously including "new" fundamental rights into the European Union legal order originating from national legal systems or from international law. Thus, the general principles of EU law ensure the flexibility of the EU legal order with regard to EU fundamental rights.

There are also other specific differences between some general principles of EU law and the equivalent rights enshrined by the EU Charter, which makes the distinction between the two categories of fundamental rights extremely relevant from a practical perspective. These specific differences are related mainly to the normative content and to the special field of application of each right and must be known and taken into consideration when the general principles of EU law and the equivalent rights enshrined by the EU Charter need to be applied by national administrative authorities or invoked before national courts as legal grounds for judicial review of the national measures. These

24 Case C-144/04, Mangold, CJEU and case C-555/07, Kücükdeveci, CJEU.

25 According to Article 6 (1) TEU.

26 Joined cases C-569/16 and C-570/16, Bauer, CJEU; case C-684/16, Max-Planck, CJEU. 
differences can be outlined from the recent case-law of the CJEU regarding some of the most often invoked EU fundamental rights in the judicial context of challenging the decisions of the administrative authorities of the Member States, when the allegedly violated right constitute both a general principle of EU law and a right laid down by the EU Charter.

\subsection{Case study. The right of defence and the presumption of innocence}

The right of defence and the presumption of innocence are protected under the EU law both as a general principle of EU law identified by CJEU and as a right laid down by Article 48 of the EU Charter.

As primary law, the right of defence provided by Article 48 of the EU Charter is binding, according to Article 51 (1) of the EU Charter, for the EU institutions, bodies, offices and agencies and also for the Member States - including all their public institutions, bodies and administrative authorities - when they implement EU law. ${ }^{27}$

As a general principle, the right of defence is binding for the EU institutions, bodies, offices and agencies and also for the Member States - including all their public institutions, bodies and administrative authorities - as a result of the decisions of the CJEU, which recognized the status of the right of defence as a general principle of EU law both before the entry into force of the EU Charter ${ }^{28}$ and after its entry into force. ${ }^{29}$

Since the interpretation of EU law held by the judgments of the CJEU is binding on all the national courts, ${ }^{30}$ it follows that the CJEU rulings in references for a preliminary ruling on the right of defence are useful in identifying situations in which the right of defence is binding for the administrative authorities of Member States and in determining when it is appropriate to claim this right as a general principle of EU law and when it is appropriate to claim it as primary EU legislation, stipulated by EU Charter.

Prior to the entry into force of the EU Charter, the right of defence, as a general principle of EU law, had an important role to play in the case-law of the CJEU, which has repeatedly held that this right is part of the EU law, and that it is binding both in procedures conducted by EU institutions and in procedures of the administrative authorities and of the public institutions of Member States. ${ }^{31}$

27 CJEU recognized the status of primary law for the right of defence in many decisions rendered after the entry into force of the EU Charter: Case T-104/13, Toshiba Corp./European Comission, CJEU; Case C-74/14, Eturas, CJEU; Case T-68/09, Soliver/European Comission, CJEU; Case C-89/11, E.ON Energie AG/ European Comission, CJEU.

28 Case C-301/87, France/European Comission, CJEU; Joined Cases C-48/90 and 66/90, Kingdom of the Netherland/ European Comission, CJEU; Case T-122/99, Procter\&Gamble, CJEU.

29 Case C-419/14, WebMindLicences, CJEU.

30 According to the principle of sincere cooperation, stipulated by Article 4 (3) TEU. Case C-61/79, Denkavit, CJEU.

31 Case C-349/07, Sopropé, CJEU, para. 33 and 36. 
CJEU held, for example, that this principle must be ensured in all proceedings which are initiated against a person and which are liable to culminate in a measure adversely affecting that person and must be guaranteed even in the absence of any specific rules. ${ }^{32}$ At the same time, CJEU ruled that observance of the right of defence is a general principle of EU law which applies where the national administrative authorities are minded to adopt a measure which will adversely affect an individual..$^{33}$

CJEU ruled also that respect for the right of defence is a general principle of EU law, according to which addressees of decisions of public authorities which perceptibly affect their interests must be enabled to express their views effectively. ${ }^{34}$ Even in the area of national fiscal administrative procedures, CJEU confirmed, in Case C-349/07 Sopropé, that the right of defence is a general principle of EU law and described the conditions that national laws and administrations have to comply with in order to make effective the exercise of the right to be heard. ${ }^{35}$

In the end, the CJEU judgements have imposed the respect of the right of defence as a general principle of EU law in any procedure carried out by the national administrative authorities and institutions of the Member States which may lead to sanctions. ${ }^{36}$

Following the entry into force of the EU Charter, the right of defence has been codified by Article 48 of the EU Charter and ranked as primary EU law, having the same legal value as the Treaties of the EU.

From this perspective, it must be determined when it is appropriate to claim, in national courts, the right of defence as general principle of EU law and when it is appropriate to claim it as primary EU legislation, stipulated by EU Charter. Also, it must be determined when the national courts must apply the right of defence as general principle of EU law and when they must apply it as a provision of EU Charter.

This issue has been addressed by CJEU, in case C-419/14, WebMindLicences, ${ }^{37}$ which concerned VAT and Directive 2006/112. In this case, the national court asked whether the national fiscal administration has, in order to ensure com-

32 Case C-301/87, France/European Commission, CJEU; Joined Cases C-48/90 and 66/90, Kingdom of the Netherland/European Comission, CJEU; Case T-122/99, Procter\&Gamble, CJEU.

33 Case C-349/07, Sopropé, para. 36.

34 Case T-122/99, Рrocter\&Gamble, CJEU, para. 42.

35 Case C-349/07, Sopropé, para. 38: "The authorities of the Member States are subject to that obligation when they take decisions which come within the scope of Community law, even though the Community legislation applicable does not expressly provide for such a procedural requirement. As regards the implementation of that principle and, in particular, the periods within which the rights of the defence must be exercised, it must be stated that, where those periods are not, as in the main proceedings, fixed by Community law, they are governed by national law on condition, first, that they are the same as those to which individuals or undertakings in comparable situations under national law are entitled and, secondly, that they do not make it impossible in practice or excessively difficult to exercise the rights of defence conferred by the Community legal order."

36 Joined Cases T-186/97, Kaufring and others, para. 151.

37 Case C-419/14, WebMindLicences, CJEU. 
pliance with the right of defence pursuant to Article 48 of the EU Charter and the principle of good administration enshrined in Article 41 of the EU Charter, the obligation to grant the taxable person access to the evidence obtained and to hear the taxable person in the course of the administrative procedure. First, CJEU reiterated the general duty of public authorities in the Member States to respect the fundamental rights guaranteed by EU law, both as general principles of EU law and especially as rights laid down in the EU Charter, in all situations governed by EU law, in the meaning established by Case C617/10, Fransson. ${ }^{38}$

Then, CJEU ruled that the provisions of Article 48 of the EU Charter are not applicable to the case, but not because the provisions of the EU Charter are not applicable to administrative proceedings of the administrative authorities of the Member States, ${ }^{39}$ but because from the wording of Article 48 of the EU Charter it follows that Article 48 is applicable only in those procedures of the national authorities involving the existence of a person 'who has been charged' (i.e. an 'accused' person), which are only the criminal and contraventional matters. ${ }^{40}$ As the procedure in question was a fiscal administrative procedure, the CJEU concluded that the administrative authorities of the Member States have the duty to respect the right of the defence as a general principle of EU law, "which applies where the authorities are minded to adopt in respect of a person a measure which will adversely affect him". ${ }^{41}$ The CJEU also established that "in accordance with this principle, the addressees of decisions which significantly affect their interests must be placed in a position in which they can effectively make known their views as regards the information on which the authorities intend to base their decision. The authorities of the Member States are subject to that obligation when they take decisions which come within the scope of EU law, even if the EU legislation applicable does not expressly provide for such a procedural requirement". ${ }^{42}$

As regards the legal remedies available at national level in the context of judicial review in case of violation of the right of defence guaranteed by EU law by the administrative authorities of the Member States, the CJEU stated that, according to Article 47 of the EU Charter, it is incumbent upon the national court which reviews the legality of the national fiscal administrative decision to verify if the national authorities have breached the right of defence and if the national court finds that the taxable person did not have the opportunity, in the context of the administrative procedure, of gaining access to the evidence and of being heard concerning it, the national court "must disregard that evidence and annul that decision if, as a result, the latter has no basis". ${ }^{43}$

38 Case C-419/14, WebMindLicences, CJEU, para. 66, 67, 68.

39 In this respect, the CJEU stressed that the provisions of the EU Charter are binding on the administrative authorities of the Member States - Case C-419/14, WebMindLicences, CJEU, рага. 68.

40 Case C-419/14, WebMindLicences, CJEU, para. 83.

41 Case C-419/14, WebMindLicences, CJEU, para. 84. For the same conclusion see Case C298/16, Ispas, CJEU, paras. 26 and 27.

42 Case C-419/14, WebMindLicences, CJEU, para. 84.

43 Case C-419/14, WebMindLicences, CJEU, para. 91. 
Another component of the right guaranteed by Article 48 of the EU Charter, which is also a general principle of the EU law, is the presumption of innocence. The CJEU case-law held that the authorities of the Member States are subject to the obligation to respect the presumption of innocence guaranteed by EU law, both as general principle of EU law ${ }^{44}$ and as a right laid down in the EU Charter, ${ }^{45}$ when they implement EU law.

In case C-74/14, ${ }^{46}$ a reference for a preliminary ruling which concerned the interpretation of Article 101 TFEU in conjunction with the presumption of innocence in the context of national judicial review of an administrative decision of the Competition Council, CJEU ruled that "the presumption of innocence constitutes a general principle of EU law, now enshrined in Article 48(1) of the EU Charter, which the Member States are required to observe when they implement EU competition law".

CJEU also held that "where the national court still has a doubt, the benefit of that doubt must be given to the undertakings accused of the infringement", according to the presumption of innocence, that "constitutes a general principle of European Union law, currently laid down in Article 48(1) of the EU Charter". ${ }^{47}$

Based on the above mentioned CJEU case-law, it can be concluded that:

- After the entry into force of the EU Charter, the right of defence and the presumption of innocence are binding under EU law both as a general principle of EU law identified by CJEU and as a right laid down by Article 48 of the EU Charter;

- The right of defence and presumption of innocence are binding both for the EU institutions, bodies, offices and agencies and also for the Member States (including all Member State public institutions, bodies and legislative/administrative authorities) when they act within the scope of EU law;

- The right of defence and the presumption of innocence are applicable as a right laid down by Article 48 of the EU Charter only in those procedures of the national authorities involving the existence of a person 'who has been charged' (i.e. an 'accused' person), which are the criminal and contraventional matters (e.g. the decisions of the national competition authorities), while in all the other matters (e.g. national fiscal administrative procedures, asylum procedures, customs procedures, etc.), the right of defence and the presumption of innocence are still applicable, but as a general principle of EU law.

44 Case C-301/87, France/European Commission, CJEU; Joined Cases C-48/90 and 66/90 Kingdom of the Netherland/ European Comission, CJEU; Case T-122/99, Procter\&Gamble, CJEU.

45 CJEU ruled that the presumption of innocence must be respected as primary law, stipulated by the EU Charter in many decisions, rendered after the entry into force of the Charter: Case T-104/13, Toshiba Corp., CJEU; Case C-74/14, Eturas, CJEU; Case T-68/09, Soliver, CJEU; Case C-89/11, E.ON Energie AG, CJEU; Case T418/10, Voestalpine AG, CJEU; Case T-398/10, Fapricela, CJEU.

46 Case C-74/14, Eturas, CJEU.

47 Case C89/11 P, E.ON Energie AG, CJEU, para. 72; Case T-104/13, Toshiba Corp., para. 50; Case T-418/10, Voestalpine, para. 116; Case T-68/09, Soliver, рага. 58. 


\subsection{Case study. The right to a good administration}

The right to a good administration is protected under EU law both as a general principle of EU law identified by CJEU and as a right laid down by Article 41 of the EU Charter.

As primary law, laid down by Article 41 of the EU Charter, the right to a good administration is binding, according to the wording of Article 41(1) of the EU Charter, only for the EU institutions, bodies, offices and agencies: "every person has the right to have his or her affairs handled impartially, fairly and within a reasonable time by the institutions, bodies, offices and agencies of the Union". ${ }^{48}$ Since Article 51(1) of the EU Charter provides that the EU Charter is binding for the EU institutions, bodies, offices and agencies and also for the Member States when they implement EU law, certain questions were raised regarding the field of application of the right to a good administration to Member States. These questions were clarified by CJEU, that held that "it is clear from the wording of Article 41 of the Charter that it is addressed not to the Member States but solely to the institutions, bodies, offices and agencies of the European Union", "which means that Article 41 of the EU Charter has a narrower scope than that of the EU Charter as a whole.

However, the right to a good administration is applicable to all Member States action within the scope of EU law - including to all public institutions, bodies and administrative authorities of the Member States - as a general principle of good administration, as established by CJEU. ${ }^{50}$

In this regard, it is relevant to observe that the wording for the right to a good administration in the first two paragraphs of Article 41 of the EU Charter is based on the previous CJEU case-law which was rendered before the entry into force of the EU Charter ${ }^{51}$ and the wording regarding the obligation to give reasons comes from Article 253 of the EC Treaty. ${ }^{52}$

According to the case-law of the CJEU, the right to good administration as general principle of EU law, which is binding on national authorities, requires that the national authorities should act impartially, fairly (transparently) and within a reasonable period of time. ${ }^{53}$ Also, according to the same principle, parties to national administrative proceedings should not be penalised by

48 Article 41 (1) of the EU Charter.

49 Case C-419/14, WebMindLicences, CJEU, para. 83; Case C141/12 and C372/12, YS and Others, para. 67; Case C166/13, Mukarubega, para. 44; Case C-482/10 Cicala, para. 28, CJEU.

50 Joined Cases C-141/12 and C-372/12, YS v. Minister voor Immigratie, Integratie en Asiel, and Minister voor Immigratie, Integratie en Asiel v. M. S., paras 66 - 69; Case C46/16, LS Customs Services, CJEU, para. 39; Case C604/12, H.N., paras. 49 and 50. For the same opinion, see also Hofmann, H.C.H. and Mihaescu, B.C. (2013). The Relation between the Charter's Fundamental Rights and the Unwritten General Principles of EU Law: Good Administration as the Test Case. European Constitutional Law Review, 9, p. 96.

51 Case C-222/86, Heylens, CJEU, para. 15; Case 374/87, Orkem, CJEU; Case C-269/90, TU München, CJEU.

52 According to the Explanations related to the EU Charter, published in OJ 2007 C 303, 14.12.2007, p. 18.

53 In Case C-604/12, HN, para 50, CJEU: "as regards the right to good administration, enshrined in Article 41 of the Charter, that right reflects a general principle of EU law". 
virtue of the fact that they did not comply with procedural rules "when this non-compliance arises from the behaviour of the administration itself ". ${ }^{.4}$

In case C46/16, LS Customs Services, CJEU held that "the right to good administration, insofar as it reflects a general principle of EU law, has requirements that must be met by the Member States when they implement EU law" . ${ }^{55} \mathrm{Con}-$ tinuing the same line of arguments in the same case, CJEU ruled that "among those requirements, the obligation to state reasons for decisions adopted by the national authorities is particularly important, since it puts their addressee in a position to defend its rights under the best possible conditions and decide in full knowledge of the circumstances whether it is worthwhile to bring an action against those decisions. It is also necessary in order to enable the courts to review the legality of those decisions." ${ }^{156}$

Also, in case C604/12, H.N., which concerned the interpretation of Directive 2004/83/EC on the qualification and status of third country nationals as refuges, CJEU ruled that the right to good administration, enshrined in Article 41 of the EU Charter reflects a general principle of EU law and, based on this principle, "where, in the main proceedings, a Member State implements EU law, the requirements pertaining to the right to good administration, including the right of any person to have his or her affairs handled impartially and within a reasonable period of time, are applicable in a procedure for granting subsidiary protection, such as the procedure in question in the main proceedings, which is conducted by the competent national authorities." ${ }^{57}$

This analysis of the CJEU's case-law regarding the right to good administration leads to the following conclusions:

- After the entry into force of the EU Charter, the right to a good administration is binding under the EU law both as a general principle of EU law identified by CJEU and as a right laid down by Article 41 of the EU Charter;

- The right to a good administration as a right laid down by Article 41 of the EU Charter is binding only for the EU institutions, bodies, offices and agencies and is not applicable to Member State action;

- The right to a good administration as a general principle of EU law identified by CJEU is binding and applicable to all Member State action within the scope of EU law, including to all public institutions, bodies and legislative/administrative authorities of the Member States.

In conclusion, the distinction between the general principles of EU law and the rights enshrined by the EU Charter is mainly relevant, from a practical perspective, in the process of identifying the most appropriate effective procedural means of claiming, in national courts, violation of EU fundamental rights by the national legislative and administrative authorities, when the violated right constitute both a general principle of EU law and a right laid down by

54 Case C-428/05, Laub GmbH \& Co., CJEU.

55 Case C-46/16, LS Customs Services, CJEU, para. 39.

56 Case C-46/16, LS Customs Services, CJEU, para. 40.

57 Case C-604/12, H.N., para. 49 and 50. 
the EU Charter. Also, the distinction between the general principles of EU law and the rights enshrined by the EU Charter can be relevant, from a practical perspective, when the national administrative authorities are in the process of issuing an administrative act in a field which is governed by EU law, because the national authorities have also the obligation to comply with EU law.

The specific differences between the general principles of EU law and the equivalent rights enshrined by the EU Charter related to the normative content and to the special field of application of each right are significant and must be evaluated before invoking in court EU fundamental rights as legal grounds for judicial review of the measures of the national authorities, because, as it clearly results from the analyzed CJEU case-law, a certain EU fundamental right might not be binding on national authorities as a right stipulated by the EU Charter, but the same EU right might be binding on national authorities as a general principle of EU law (e.g. the right to a good administration). Also, in the same context of the judicial review, even if a certain EU fundamental right is binding as a right stipulated by the EU Charter only in some specific national administrative procedures, depending on the subject matter of the procedure, the same EU right might be binding in all national administrative procedures as a general principle of EU law (e.g. the EU right of defence and the presumption of innocence).

\section{Judicial national review of national administrative measures under the EU Charter of Fundamental Rights and under the general principles of EU law}

In case the national legislative and administrative authorities do not comply with the provisions of the EU Charter or with the general principles of EU law, it is opened the possibility of the judicial review, guaranteed by another EU fundamental right laid down by Article 47 of the EU Charter - the right to an effective remedy and to a fair trial.

That means that where the EU Charter or the general principles of EU law apply (or both), based on the direct effect of the EU Charter and of the general principles of EU law, individuals ${ }^{58}$ can rely in national courts, in the context of judicial review, on the provisions of the EU Charter or on the general principles of EU law, against Member States (i.e. against any national legislative or administrative authorities) to claim the violation of their fundamental rights laid down by the EU Charter or recognized as general principles of EU law and to obtain an effective remedy.

Although the direct effect of the EU Charter was seen mainly vertical, based on a strict interpretation of the wording of Article 51 of the EU Charter, immediately after the entry into force of the EU Charter, the CJEU acknowl-

58 In the category of the beneficiaries that can rely on the EU Charter and on the general principles of EU law can be included private legal persons, corporations or other legal entities. In this context, it is relevant case C-279/09, DEB, CJEU. 
edged later, in its recent case-law, ${ }^{59}$ the possibility of the horizontal direct effect of the EU Charter and has then admitted the possibility of relying on certain rights conferred by the EU Charter in disputes between private parties before national courts.

In connection with the violation of the EU Charter and of the general principles of EU law by the national authorities, the CJEU will have the jurisdiction to interpret provisions of the EU Charter and general principles of EU law in connection with Member States actions, based on Article 267 TFEU, whilst the national courts will be bound to apply the EU Charter and the general principles of EU law whenever EU law will play a role, in the context of national judicial review.

The effects of the EU Charter and of the general principles of EU law within the national law and before the national courts - i.e. the primacy over the contrary national law, the direct effect and the direct applicability - follow directly from EU law and from case-law of the CJEU and not from the national Constitutions or national law.

Given the fact that the EU Charter has the same legal value as the EU Treaties $^{60}$ and that the CJEU has recognized the direct effect for the provisions of EU Treaties whenever they confer rights to the individuals and are sufficiently precise and unconditional, ${ }^{61}$ it follows that also the provisions of the EU Charter must comply the same conditions in order to have direct effect. ${ }^{62}$

Thus, whenever the provisions of the EU Charter confer rights to the individuals and are sufficiently precise and unconditional, based on the vertical direct effect of the EU Charter, the individuals can invoke the EU Charter in national courts and the national courts are obliged to review the acts of the national legislative and administrative authorities for conformity with the EU Charter, whenever the national acts or measures fall within the scope of EU law. That implies that, in case the national courts find that the acts of the national legislative and administrative authorities violated the EU Charter, the national courts may render inapplicable the national legislation conflicting with EU Charter and may also, in certain conditions, decide the annulment of the reviewed national action.

Moreover, based on the horizontal direct effect of the EU Charter, which was acknowledged recently by the CJEU, ${ }^{63}$ whenever a provision of the EU Charter is sufficient in itself to confer on individuals a right which they may rely on as such in a dispute with another individual, that provision can be invoked in disputes between private parties, too, before national courts.

59 Joined cases C-569/16 and C-570/16, Bauer, CJEU, paras 84-86; case C-684/16, Max-Planck, CJEU, paras 73-75.

60 According to Article 6 (1) TEU.

61 Case C-26/62, Van Gend \& Loos, CJEU.

62 Case C-176/12, AMS, CJEU.

63 Joined cases C-569/16 and C-570/16, Bauer, CJEU, paras 84-86; case C-684/16, Max-Planck, CJEU, paras 73-75. 
According to the 'right to obtain an effective remedy in a competent court', which is enshrined in Article 47 of EU Charter and Articles 6 and 13 ECHR, but is also protected as a fundamental general principle of EU law, ${ }^{64}$ the national courts have the obligation, where they find a violation of a fundamental right protected under EU law, to grant a remedy to ensure its enforcement. The EU fundamental rights would be useless if individuals affected by measures of the European Union or of the Member States acting within the scope of European Union law were not able to challenge in court measures affecting their interests (Hofmann et al., 2011, p. 204). Since the national courts have the most important role in ensuring, at national level, the judicial protection of rights under EU law, judicial review of national measures for compliance with EU fundamental rights must always be governed by the right to an effective remedy and to a fair trial and by the conditions laid down in Article 47 of the EU Charter.

Although the detailed procedural rules designed to ensure the protection of the rights which were acquired under EU law are a matter for the national legal order of each Member State, in accordance with the principle of the procedural autonomy of the Member States, it must be emphasized that CJEU held clearly that Member States may apply their procedural autonomy provided, however, that national procedural rules are not less favorable than those governing similar domestic situations (principle of equivalence) and that they do not render impossible in practice or excessively difficult the exercise of rights conferred by the European Union legal order (principle of effectiveness). ${ }^{65}$ In this respect, it must be also pointed out that CJEU held that the application of the national procedural autonomy is subsidiary to explicit EU law. ${ }^{66}$

\subsection{Case study. Judicial review in Romania of national action under the EU Charter or under the general principles of EU law}

After the entry into force of the EU Charter, it was noticed, in practice, an increased interaction between the CJEU and the national courts of the Member States, in the context of the preliminary reference procedure, in cases regarding the application of the EU Charter (Vrabie, 2017, p. 238). ${ }^{67}$

The entry into force of the EU Charter has strengthened also the role of national courts of the Member States in the application of EU law, by adding an important legally binding instrument in the field of protection of fundamental rights that must be taken into account and applied by the national courts when EU Member States are implementing EU law. This multiplication of the legal instruments for the protection of fundamental rights on EU level can result in contradictions between national legislation and the provisions of the EU Charter, that must be solved by the national courts (Vrabie, 2017, pp. 227228).

64 Case C-85/76, Hoffmann-La Roche v Commission, para. 9; Case C-222/84, Johnston, para. 19.

65 Case C-298/16, Ispas, CJEU, para. 29; for the same reasoning, see also Case C14/16, Euro Park Service, para. 36.

66 Case C-33/76 Rewe-Zentralfinanz, CJEU, para. 5.

67 See also the preliminary reference made by the Spanish Constitutional Court in case C-399/11, Melloni, CJEU. 
In Romania, the judicial review of national measures under the EU Charter was considered by the Constitutional Court after the entry into force of the EU Charter. In 2012, the Constitutional Court declared that 'it is clear from the case-law of the CJEU that the EU Member States are required to comply with the EU fundamental rights enshrined by EU law, when they are implementing EU law' and acknowledged that this rule, as provided by the EU Charter, applies equally to central authorities and to regional or local courts, as well as to public bodies when they are implementing EU law; therefore, the Romanian Constitutional Court concluded that EU Member States should apply the EU fundamental rights enshrined by the EU Charter. ${ }^{68}$

It must be pointed out also that the Romanian Constitutional Court acknowledged the legal status and the legal force of the EU Charter, ruling that EU Charter is a legal instrument having the same legal force as the constitutive treaties of the European Union. ${ }^{69}$

After acknowledging the EU Charter as a legally binding instrument, in 2015, the Romanian Constitutional Court exercised the constitutionality control of a provision of national law by using EU law - including a provision of the EU Charter - as a legal ground. The Constitutional Court ruled that Article 153 (1) TFEU, Article 27 from the EU Charter and Articles 2 and 3 from the Directive $98 / 59 / C E$, can be used in the context of judicial control of constitutionality of national law, as 'interposed norms of EU law', because these EU law provisions were sufficiently clear, precise and unconditional and had a certain level of constitutional relevance that can support the violation of the Romanian Constitution. Thus, the Court concluded that the national law in question was unconstitutional. ${ }^{70}$

After the Directive 2006/24/CE was invalidated by the CJEU in case Digital Rights Ireland $L t d^{71}$ for breaching Articles 7 and 8 of the EU Charter, the Romanian Constitutional Court was called to review the constitutionality of a national law that transposed the Directive 2006/24/EC. In this case, the Constitutional Court used the opportunity to refer to Articles 7 and 8 of the EU Charter, quoting also the most relevant fragments from the reasoning of the CJEU in case Digital Rights Ireland Ltd. ${ }^{72}$

In 2016, when the Romanian Constitutional Court submitted its first preliminary question to the CJEU, in case Coman, ${ }^{73}$ the preliminary question was also related to the EU Charter. The case concerned Article 277 of the Romanian Civil Code which provided that marriages between same-sex persons conclu-

68 Romanian Constitutional Court, decision no. 53/25.01.2012, published in the Official Journal of Romania no. 234/06.06.2012.

69 Romanian Constitutional Court, decision no. 967/20.11.2012, published in Official Journal of Romania no. 853/18.12.2012.

70 Romanian Constitutional Court, decision no. 64/24.02.2015, published in Official Journal of Romania no. 286/28.04.2015.

71 Joined Cases C293/12 and C594/12, Digital Rights Ireland Ltd, CJEU.

72 Joined Cases C293/12 and C594/12, Digital Rights Ireland Ltd, CJEU.

73 Case C-673/16, Coman, CJEU. Case no. 78D/2016 of the Constitutional Court of Romania. 
ded in other countries are not recognized in Romania and Article 21 (1) TFEU and Article 7 (2) of Directive 2004/38/EC. ${ }^{74}$

The case was generated by the refusal of the Romanian authorities to grant a right of residence in Romania for more than three months to a third-country national based on a marriage lawfully concluded abroad between a EU citizen and his spouse of the same sex, a third-country national, based on the ground that marriage between people of the same sex was not recognized by Romanian law. In the context of constitutionality control, the Constitutional Court asked the CJEU for an interpretation of Articles 2(2)(a), 3(1) and 7([2]) of Directive 2004/38, read in the light of Articles 7, 9, 21 and 45 of the EU Charter, asking whether these EU law provisions require the Member State to grant the right of residence in its territory for a period of longer than three months to the same-sex spouse of a citizen of the EU. The CJEU held that Article 21(1) TFEU is to be interpreted as meaning that, in circumstances such as those of the main proceedings, a third-country national has the right to reside in the territory of the Member State for more than three months and that derived right of residence cannot be made subject to stricter conditions than those laid down in Article 7 of Directive 2004/38. ${ }^{75}$

Finally, the Constitutional Court embraced the interpretation of the CJEU and decided to use EU law provisions as interposed norms integrated in the standard of review for the control of constitutionality of national law. Thus, the Court declared that the provisions of Article 277 of the Romanian Civil Code are constitutional only to the extent that they allow granting of the right of residence on the territory of the Romanian state, under the conditions stipulated by EU law, to the spouses - citizens of the Member States of the European Union and/or third-country nationals - from same-sex marriages, concluded in a Member State of the European Union. ${ }^{76}$

Regarding the judicial review of the action of the Romanian administrative authorities for compliance with EU law (EU fundamental rights included), it must be pointed out that, besides the primacy of EU law, direct applicability of EU law and the direct effect of EU law, which allow any national ordinary court to apply the EU fundamental rights when a breach of these rights is invoked and ascertained, the Romanian legal system provides also a special revision procedure.

Article 21 of the Law no. 554/2004 on administrative proceedings ${ }^{77}$ allows the national ordinary courts to revise and to change the final court decisions (having the authority of res judicata) which are incompatible with EU law,

74 Directive 2004/38/EC of the European Parliament and of the Council of 29 April 2004 on the right of citizens of the Union and their family members to move and reside freely within the territory of the Member States amending Regulation (EEC) No 1612/68 and repealing Directives 64/221/EEC, 68/360/EEC, 72/194/EEC, 73/148/EEC, 75/34/EEC, 75/35/EEC, 90/364/ EEC, 90/365/EEC and 93/96/EEC.

75 Case C-673/16, Coman, CJEU.

76 Romanian Constitutional Court, decision no. 534/18.07.2018, published in Official Journal of Romania no. 842/03.10.2018.

77 Published in Official Journal of Romania no. 1154/07.12.2004. 
delivered in the course of administrative proceedings, as a special revision procedure.

In this context, it must be mentioned that the Constitutional Court acknowledged, by decision no. $1609 / 2010,{ }^{78}$ the possibility of the judicial revision of the definitive court decisions delivered in administrative litigation, in case these definitive decisions breach the principle of the primacy of EU law. This decision of the Constitutional Court was confirmed also by the High Court of Cassation and Justice (panel of judges for interpreting Romanian law), in decision no. 45/12.12.2016 ${ }^{79}$ (which is mandatory for all the Romanian courts), where it was declared that this procedural possibility of revisiting the final judgements must be recognized also in case of non-compliance with the interpretation of EU law given by the Court of Justice of the European Union after the moment of the delivery of the final judgement. Thus, in the Romanian legal system, the special revision procedure provided by Article 21 of the Law no. 554/2004 on administrative proceedings can be used not only to revise final judgments that are incompatible with the provisions of EU law (e.g. the EU Charter), but also to revise final judgments that are incompatible with the general principles of EU law and with the interpretations of EU law adopted by the Court of Justice of the European Union.

\section{Conclusion}

First of all, this study shows beyond doubt that the entry into force of the EU Charter as binding primary law did not influence, in a negative way, the existence and the validity of the EU's core values which were guaranteed as general principles of EU law long before the entry into force of the EU Charter. On the contrary, the general principles of EU law and the EU Charter of Fundamental Rights are coexisting, according to Article 6 TEU and according to the analyzed post-Lisbon CJEU case-law, in the complex system of the protection of fundamental rights of the European Union, as different sources of EU fundamental rights.

The most important consequence of this plurality of sources of fundamental rights at EU level, which are also binding at national level, under some conditions, is that the sources can be combined and invoked alternatively for a better protection of individuals - as general principles of EU law or as fundamental rights laid down by the EU Charter - in the context of judicial review in case of violation of EU fundamental rights, based on the particularities of the case.

Although the general rule regarding the application of EU fundamental rights to Member State action is that EU fundamental rights (regardless if they are guaranteed as general principles of EU law or by the EU Charter) are binding to all national authorities, institutions and bodies of the Member States when they are acting within the scope of EU law, ${ }^{80}$ there are many differences and

78 Romanian Constitutional Court, decision no. 1609/09.12.2010, published in the Official Journal of Romania no. 70/27.01.2011.

79 Published in Official Journal of Romania no. 386/23.05.2017.

80 Terminology that must be understood in the light of Case C-617/10, Fransson, CJEU. 
conditions that must be taken into consideration in determining when it is appropriate to claim in court EU fundamental rights as general principles of EU law and when it is appropriate to claim in court EU fundamental rights as primary law, laid down by EU Charter of Fundamental Rights. The EU fundamental rights and the differences between general principles of EU law and the EU Charter must be taken into consideration also by the national administrative bodies when they are issuing various administrative acts in the fields that are governed by EU law (competition, protection of environment, VAT, customs, consumer protection, public procurement, etc.), because if an administrative act is not compatible with EU law might be annulled in the judicial administrative proceedings.

The study shows also that EU fundamental rights, guaranteed as general principles of EU law or laid down by the EU Charter, are not just a list of values, but they are useful legal instruments that can be invoked as legal grounds in national courts when these EU fundamental rights are violated by national authorities.

The legal remedies that can be granted by the national courts in the context of the judicial review of the Member State action when violation of EU fundamental rights is invoked and it is ascertained by court can even lead to the annulment of the measures of the national authorities (regardless if they are guaranteed by general principles or by the EU Charter), under some conditions established by CJEU. ${ }^{81}$ In this context, CJEU held, for example, that "according to EU law, an infringement of the rights of the defence, in particular the right to be heard, results in the annulment of the decision taken at the end of the administrative procedure at issue only if, had it not been for such an irregularity, the outcome of the procedure might have been different" ${ }^{82}$

The possibility to claim in court the violation of EU fundamental rights guaranteed as general principles of EU law or laid down by the EU Charter against the national authorities and to obtain an effective legal remedy for such violation (like the annulment of the administrative measure or compensatory damages) in the context of a fair judicial review, is guaranteed by another EU fundamental right laid down by Article 47 of the EU Charter - the right to an effective remedy and to a fair trial. Also, the right to an effective legal remedy in the context of judicial review in case of violation of EU fundamental rights by the national authorities derives from the principle of sincere cooperation ${ }^{83}$ and from the principle of effectiveness of EU law. ${ }^{84}$

81 Case C-419/14, WebMindLicences, CJEU, para. 91. The condition mentioned by CJEU in this case made reference to the lack of basis of the administrative decision, as a result of disregarding the evidence that was obtained by the administrative authority with the violation of the right of defence.

82 Joined cases C129/13 and C130/13, Kamino International \& Datema Hellmann, CJEU, paras. 78, 79, 80. See also, for the same reasoning, Case C301/87, France $\vee$ Commission, para. 31; Case C288/96, Germany v Commission, para. 101; Case C141/08 P, Foshan Shunde Yongjian Housewares \& Hardware v Council, para. 94.

83 Article 4 (3) TEU and Article 288 TFEU.

84 Case C298/16, Ispas, CJEU, para. 29. 


\section{References}

Bazzocchi, V. (2011). The European Charter of Fundamental Rights and the Courts. In G. Di Federico, ed., The EU Charter of Fundamental Rights: From Declaration to Binding Instrument. Dordrecht: Springer, pp. 55-75.

Charter of Fundamental Rights of the European Union, OJ C 326, 26. 10. 2012, pp. 391-407.

Council of the European Union. (2017). The Conclusions on the application of the EU Charter of Fundamental Rights in 2016. At <http://data.consilium.europa. eu/doc/document/ST-12913-2017-INIT/en/pdf>, accessed 10 April 2019.

Court of Justice of the European Union. CJEU. At < https://curia.europa.eu/jcms/ jcms/j_6/en/>, accessed 10 April 2019.

Craig, P. (2010). The Lisbon Treaty: Law, Politics and Treaty Reform. Oxford: Oxford University Press.

Craig, P. and de Burca, G. (2011). EU Law, Text, Cases and Materials. Fifth Edition. Oxford: Oxford University Press.

Di Federico, G. (2011). Fundamental Rights in the EU: Legal Pluralism and MultiLevel Protection after the Lisbon Treaty. In G. Di Federico, ed., The EU Charter of Fundamental Rights: From Declaration to Binding Instrument. Dordrecht: Springer, pp. 15-54.

Directive 2004/38/EC of the European Parliament and of the Council of 29 April 2004 on the right of citizens of the Union and their family members to move and reside freely within the territory of the Member States amending Regulation (EEC) No 1612/68 and repealing Directives 64/221/EEC, 68/360/ EEC, 72/194/EEC, 73/148/EEC, 75/34/EEC, 75/35/EEC, 90/364/EEC, 90/365/ EEC and 93/96/EEC.

Eeckhout P. (2002). The EU Charter of Fundamental Rights and the Federal Question. Common Market Law Review, 39 (5), pp. 945-994.

Explanations related to the Charter of Fundamental Rights of the European Union, OJ 2007, C 303, 14. 12. 2007, pp. 17-35.

European Commission. (2018). 2017 report on the application of the EU Charter of Fundamental Rights. Luxembourg: Publications Office of the European Union. At <https://ec.europa.eu/info/sites/info/files/2017_annual_charter_ report_en.pdf>, accessed 10 April 2019.

European Commission. (2019). 2018 report on the application of the EU Charter of Fundamental Rights. At <https://op.europa.eu/en/publication-detail/-/ publication/784b02a4-a1f2-11e9-9d01-01aa75ed71a1/language-en>, accessed 25 February 2020.

European Union Agency for Fundamental Rights. (2018). Applying the Charter of Fundamental Rights of the European Union in law and policymaking at national level. Luxembourg: Publications Office of the European Union. At <https://fra.europa.eu/sites/default/files/fra_uploads/fra-2018-charterguidance_en.pdf>, accessed 10 April 2019.

Garcia, R. A. (2002). The General Provisions of the Charter of Fundamental Rights. European Law Journal, 8(4), pp. 492-514.

Hofmann, H.C.H. and Mihaescu, B.C. (2013). The Relation between the Charter's Fundamental Rights and the Unwritten General Principles of EU Law: Good Administration as the Test Case. European Constitutional Law Review, 9, pp. 73-101. 
Hofmann, H.C.H. et al. (2011). Administrative Law and Policy of the European Union. Oxford: Oxford University Press.

Lenaerts, K. (2010). La solidarité ou le chapitre IV de la Charte des droits fondamentaux de l'Union européenne. Revue trimestrielle des droits de l'homme, 82, pp. 217-236.

Official Journal of Romania, 1154, 7. 12. 2004.

Official Journal of Romania, 386, 23. 5. 2017.

Romanian Constitutional Court, Decision no. 1609/9. 12. 2010. Official Journal of Romania, 70, 27. 1. 2011.

Romanian Constitutional Court, Decision no. 53/25. 1. 2012. Official Journal of Romania, 234, 6. 6. 2012.

Romanian Constitutional Court, Decision no. 967/20. 11. 2012. Official Journal of Romania, 853, 18. 12. 2012.

Romanian Constitutional Court, Decision no. 64/24. 2. 2015. Official Journal of Romania, 286, 28. 4. 2015.

Schwarze, J. (2001). A German View on the European Charter of Fundamental Rights: Effect on the Bundesverfassungsgericht. Cambridge Yearbook of European Legal Studies, 3, pp. 407-410.

Treaty of Lisbon amending the Treaty on European Union and the Treaty establishing the European Community, OJ C 306, 17. 12. 2007 (entry into force on 1 December 2009).

Tridimas, T. (2005). The General Principles of EU Law. Oxford: Oxford University Press.

Vrabie, M. (2017). Judicial protection of the Charter of Fundamental Rights of the European Union. Bucharest: Editura Universul Juridic. 